\title{
Students' Preferences for the Teachers' Characteristics and Traits in Character Building of Students with Special Needs
}

\author{
Dr. Samina Ashraf \\ Assistant Professor,DSE, P.U. \\ Dr. Humara Bano \\ Assistant Professor, DSE,P.U \\ Miss. Ayisha llyas \\ Miss. Fatima Abur Rehman \\ Department of Special Education, P.U..
}

Doi:10.5901/mjss.2013.v4n4p423

\begin{abstract}
Teacher plays a major role in creating a moral and ethical community in the classroom. Teachers' characteristics and traits including both positive and negative shape the students behavior. The main objectives of the study were to highlight the preferences of students with special needs for teachers' characteristics and traits in their character building, and to find out the traits of an ideal special education teacher. A sample of the 45 students with special needs was selected from the five universities of Lahore. A close ended questionnaire was used to elicit the responses of students. Data were analyzed and it was found that majority of the students responded that teachers' characteristics have direct influence in the character building of the students moreover they prefer teachers with positive characteristics for their good moral and ethical development.
\end{abstract}

\section{Introduction}

Teaching is an art and central to education. We cannot have education without teaching. It is an important part of social event of human beings to share meanings. Teaching requires authority. Teacher is a main actor in the process of teaching (Cooper, 2002). Teachers has a tremendous power to influence the thinking, motivation and knowledge of their students. Teacher's personality has so many dimensions which affects students in grooming their personality and to build up their character. Leaman (2008) summarized his thoughts on teacher effectiveness that a good teacher is a good person, simple and true. A good teacher likes life, has a sense of humor, and enjoys other people. The good teacher is flexible. By far, the single most repeated adjective used to describe good teachers is "flexible"( Brophy, Good,1986; Moore, 2004).

Teacher's role is very important in character building of their students. Students follow their teacher as a role model. A teacher, having a caring behavior, focusing on respect of students, being firm with rules and friendly with individual, can be a good teacher according to the student's point of view. On the other hand, being dull and un-engaging, being uncaring, not making an effort and rude behavior with students can make students fed up and uninteresting in studies and learning activities (Leaman, 2008).

Many researchers believed that there are five core personality traits of teachers which related with character building of students. This idea of five core personality traits has been growing over the past 50 years, beginning with the research of Fiske (1949) and later expanded upon by other researchers including Norman (1967), Smith (1967), Goldberg (1981), and McCrae \& Costa (1987). These five categories included following characteristics: extraversion, agreeableness, conscientiousness, neuroticism and openness.

Extraversion is characterized by positive emotions, and the tendency to seek out stimulation and the company of others. The trait is marked by pronounced engagement with the external world. Extraverts enjoy being with people, and are often perceived as full of energy. This trait includes characteristics such as excitability, sociability, talkativeness, assertiveness and emotional expressiveness. Agreeableness is a tendency to be compassionate and cooperative. 
Agreeable people also have an optimistic view of human nature. This personality dimension includes attributes such as trust, altruism, kindness, affection and love ( Feist and Fiest, ,2006).

Conscientiousness is a tendency to show self-discipline, act dutifully, and aim for achievement. The trait shows a preference for planned rather than spontaneous behavior.

Common features of this dimension include high levels of thoughtfulness, good impulse control and goal-directed behaviors. Neuroticism is the tendency to experience negative emotions, such as anger, anxiety, or depression. It is sometimes called emotional instability, or is reversed and referred to as emotional stability. According to Eysenck's (1967) theory of personality, neuroticism is interlinked with low tolerance for stress or aversive stimuli. Individuals high in this trait tend to experience emotional instability, anxiety, moodiness, irritability and sadness. Openness is a general appreciation for art, emotion, adventure, unusual ideas, imagination, curiosity, and variety of experience. People who are open to experience are intellectually curious, appreciative of art, and sensitive to beauty. This trait features characteristics such as imagination, insight and forward look ( Clark, 1993).

While talking about students' preferences it is observed that students preferred the teacher who is caring for them, appreciating them while learning new knowledge and information, helps them in learning process and shares his own life experiences with them to make them realize about the facts. Special students have their own needs and requirement (Giladi \& Ben-Peretz,1981).

Special education is a challenging field which involves many responsibilities. Those who possess the characteristics of a good special education teacher and persist in meeting their goals will contribute to the success and productivity of many children with special needs. Teacher's characteristic and behavior provide positive changes in student's character. This research concerned with specific teachers characteristics and traits which are preferred by students with special need in their character building. This research will lights up the shadows of the teacher personality's such characteristics and traits which have a deep impact on students' character building.

\section{Objectives of the Study}

The objectives of this research were to

1. Identify the preferences of students for teacher's traits specific to their character building.

2. Find out the traits of teacher related to the character building of students with special needs.

3. Highlight the views of students about their teachers, regarding the traits of ideal special education teacher.

4. Find out the difference between the preferences of male and female students with special needs.

\section{Methodology}

It was a descriptive type of research. The population of the study included students with special needs presently studying in the universities of Lahore. A sample of 45 students with special needs (male=20, female=25) was selected through convenient sample technique. Among sample 21 students were from University of the Punjab, Lahore, 6 students were from Government collage University, 8 students were from Lahore Collage University, 6 students were from University of Management and Technology and only 4 students were from University of Central Punjab. Out of 45 special students 19 students were physically handicapped, 12 were visually impaired and 14 were hearing impaired.

Students' preferences were measured by the self -constructed questionnaire which was developed on the basis of literature review. The instrument consisted of 30 close ended items. The respondents were provided five points scale to respond each statement. The responses were coded from 1 to 5 i.e.,1=definitely not true of me (DNTM), 2=seldom true of me(STM), 3 sometimes true of me(SOTM) ,4=often true of me (OTM) and $5=$ definitely true of me(DTM).

By using this instrument data was collected from above mentioned five universities of Lahore city. The data were analyzed by SPSS. Major performed analysis included frequency analysis along with percentages of responses and cross tabulation.

\section{Findings}

The following findings have been derived on the basis of data analysis:

I. Majority of the students $(60.0 \%)$ responded that their teacher's excited behavior makes them excited too.

2. Majority of the students $(51.1 \%)$ responded that their teacher's good social relations with others help them in their sociability. 
3. Majority of the students $(48.9 \%)$ responded that their teacher's conversation in friendly way helps them to establish good relation with others.

4. Majority of the students $(46.7 \%)$ responded that their teacher's confident attitude makes them confident.

5. Majority of the students $(40.0 \%)$ responded that their teacher's trust on students helps them to trust on other people.

6. Majority of the students (42.2\%) responded that their teacher's kind attitude develops gentleness in them.

7. Majority of the students $(33.3 \%)$ responded that their teacher's lovely attitude creates love \& affection for others in them.

8. Majority of the students (44.4\%) responded that their teacher's consideration in every affair creates the habit of consideration in them.

9. Majority of the students $(42.2 \%)$ responded that their teacher's ability to bear negative circumstances creates tolerance in them.

I0. Majority of the students (33.3\%) responded that their teacher's firmness in his/her aims make them firm too.

II. Majority of the students $(44.4 \%)$ responded that their teacher's emotionally instable attitude makes them emotionally instable too.

I2. Majority of the students (26.7\%) responded that their teacher's restless behavior developed uneasiness in them.

I3. Majority of the students (31.1\%) responded that their teacher's irritability makes them irritable too.

I4. Majority of the students (33.3\%) responded that their teacher's sad nature makes them depressed.

I5. Majority of the students (42.2\%) responded that their teacher's outlook \& insight nature makes them forward look too.

I6. Majority of the students $(37.8 \%)$ responded that their teacher's sincerity with his/her job develops the passion of honesty in them.

17. Majority of the students (37.8\%) responded that their teacher's ability to accomplish his/her duties awoke sense of responsibility in them.

18. Majority of the students (44.4\%) responded that their teacher's neatness \& attractiveness helps them to groom their personality.

19. Majority of the students $(46.7 \%)$ responded that their teacher's sensitiveness toward solving the problems motivates them to solve the problem of others.

20. Majority of the students (48.9\%) responded that their teacher's courtesy motivates them to be courteous.

2I. Majority of the students $(44.4 \%)$ responded that their teacher's punctuality makes them punctual too.

22. Majority of the students $(35.6 \%)$ responded that their teacher's maintained personality helps them to makes their personality also attractive.

23. Majority of the students $(37.8 \%)$ responded that their teacher's contemplation of social traditions \& moral values also enables them to follow these values.

The responses of the students are presented in the following tables.

Item No. 1: My teachers' exciting behavior also makes me excited

\begin{tabular}{|l|l|l|}
\hline Responses & Frequency & Percentage \\
\hline Definitely not true of me & 4 & 8.9 \\
\hline Seldom true of me & 6 & 13.3 \\
\hline Sometimes true of me & 2 & 4.4 \\
\hline Often true of me & 6 & 13.3 \\
\hline Definitely true of me & 27 & 60.0 \\
\hline
\end{tabular}

Item No. 2: My teacher's good social relation with others helps me to develop Socially.

\begin{tabular}{|l|l|l|}
\hline Responses & Frequency & Percentage \\
\hline Definitely not true of me & 4 & 8.9 \\
\hline Seldom true of me & 6 & 13.3 \\
\hline Sometimes true of me & 2 & 4.4 \\
\hline Often true of me & 6 & 13.3 \\
\hline Definitely true of me & 27 & 60.0 \\
\hline
\end{tabular}


Item No. 3: My teacher's good communication helps me to develop good relation with others.

\begin{tabular}{|l|l|l|}
\hline Responses & Frequency & Percentage \\
\hline Definitely not true of me & 3 & 6.7 \\
\hline Seldom true of me & 6 & 13.3 \\
\hline Sometimes true of me & 6 & 13.3 \\
\hline Often true of me & 8 & 17.8 \\
\hline Definitely true of me & 22 & 48.9 \\
\hline
\end{tabular}

Item No. 4: My teacher's confident attitude gives me confidence

\begin{tabular}{|l|l|l|}
\hline Responses & Frequency & Percentage \\
\hline Definitely not true of me & 4 & 8.9 \\
\hline Seldom true of me & 5 & 11.1 \\
\hline Sometimes true of me & 7 & 15.6 \\
\hline Often true of me & 8 & 17.8 \\
\hline Definitely true of me & 21 & 46.7 \\
\hline
\end{tabular}

Item No. 5: My teacher's trust worthy relationship with students helps me to trust other.

\begin{tabular}{|l|l|l|}
\hline Responses & Frequency & Percentage \\
\hline Definitely not true of me & 4 & 8.9 \\
\hline Seldom true of me & 5 & 11.1 \\
\hline Sometimes true of me & 11 & 24.4 \\
\hline Often true of me & 7 & 15.6 \\
\hline Definitely true of me & 18 & 40.0 \\
\hline
\end{tabular}

Item No. 6: My teacher's affectionate behavior helps me to develop gentleness in me.

\begin{tabular}{|l|l|l|}
\hline Responses & Frequency & Percentage \\
\hline Definitely not true of me & 2 & 4.4 \\
\hline Seldom true of me & 6 & 13.3 \\
\hline Sometimes true of me & 9 & 20.0 \\
\hline Often true of me & 9 & 20.0 \\
\hline Definitely true of me & 19 & 42.2 \\
\hline
\end{tabular}

Item No. 7: My teacher's love with others helps me to deal affectionately with people.

\begin{tabular}{|l|l|l|}
\hline Responses & Frequency & Percentage \\
\hline Definitely not true of me & 6 & 13.3 \\
\hline Seldom true of me & 11 & 24.4 \\
\hline Sometimes true of me & 13 & 28.9 \\
\hline Often true of me & 15 & 33.3 \\
\hline Definitely true of me & 6 & 13.3 \\
\hline
\end{tabular}

Item No. 8: My teachers' considerations in every affair help me to consider other's problems seriously.

\begin{tabular}{|l|l|l|}
\hline Responses & Frequency & Percentage \\
\hline Definitely not true of me & 1 & 2.2 \\
\hline Seldom true of me & 8 & 17.8 \\
\hline Sometimes true of me & 9 & 20.0 \\
\hline Often true of me & 7 & 15.6 \\
\hline Definitely true of me & 20 & 44.4 \\
\hline
\end{tabular}


Item No. 10: My teachers' habit of managing the negative situations creates tolerance in me.

\begin{tabular}{|l|l|l|}
\hline Responses & Frequency & Percentage \\
\hline Definitely not true of me & 4 & 8.9 \\
\hline Seldom true of me & 7 & 15.6 \\
\hline Sometimes true of me & 9 & 20.0 \\
\hline Often true of me & 6 & 13.3 \\
\hline Definitely true of me & 19 & 42.2 \\
\hline
\end{tabular}

Item No. 11: My teacher's determination in his/her aims promotes determination in me.

\begin{tabular}{|l|l|l|}
\hline Responses & Frequency & Percentage \\
\hline Definitely not true of me & 3 & 6.7 \\
\hline Seldom true of me & 6 & 13.3 \\
\hline Sometimes true of me & 10 & 22.2 \\
\hline Often true of me & 11 & 24.4 \\
\hline Definitely true of me & 15 & 33.3 \\
\hline
\end{tabular}

Item No. 12: My teacher's instable emotional attitude makes me emotionally In-stable .

\begin{tabular}{|l|l|l|}
\hline Responses & Frequency & Percentage \\
\hline Definitely not true of me & 4 & 8.9 \\
\hline Seldom true of me & 4 & 8.9 \\
\hline Sometimes true of me & 11 & 24.4 \\
\hline Often true of me & 20 & 44.4 \\
\hline Definitely true of me & 6 & 13.3 \\
\hline
\end{tabular}

Item No. 13: My teacher's restlessness makes me uneasy.

\begin{tabular}{|l|l|l|}
\hline Responses & Frequency & Percentage \\
\hline Definitely not true of me & 6 & 13.3 \\
\hline Seldom true of me & 8 & 17.8 \\
\hline Sometimes true of me & 7 & 15.6 \\
\hline Often true of me & 12 & 26.7 \\
\hline Definitely true of me & 12 & 26.7 \\
\hline
\end{tabular}

Item No. 14: My teacher's irritable mood makes me irritable too.

\begin{tabular}{|l|l|l|}
\hline Responses & Frequency & Percentage \\
\hline Definitely not true of me & 13 & 28.9 \\
\hline Seldom true of me & 7 & 15.6 \\
\hline Sometimes true of me & 5 & 11.1 \\
\hline Often true of me & 6 & 13.3 \\
\hline Definitely true of me & 14 & 31.1 \\
\hline
\end{tabular}

Item No. 15: My teacher's sad mood makes me depressed.

\begin{tabular}{|l|l|l|}
\hline Responses & Frequency & Percentage \\
\hline Definitely not true of me & 4 & 8.9 \\
\hline Seldom true of me & 4 & 8.9 \\
\hline Sometimes true of me & 8 & 17.8 \\
\hline Often true of me & 15 & 33.3 \\
\hline Definitely true of me & 14 & 31.1 \\
\hline
\end{tabular}


Item No. 16: My teacher's insight and foreseeing nature makes me foreseeing too.

\begin{tabular}{|l|l|l|}
\hline Responses & Frequency & Percentage \\
\hline Definitely not true of me & 3 & 6.7 \\
\hline Seldom true of me & 4 & 8.9 \\
\hline Sometimes true of me & 13 & 28.9 \\
\hline Often true of me & 6 & 13.3 \\
\hline Definitely true of me & 19 & 42.2 \\
\hline
\end{tabular}

Item No. 17: My teacher's responsible behavior makes me responsible too.

\begin{tabular}{|l|l|l|}
\hline Responses & Frequency & Percentage \\
\hline Definitely not true of me & 1 & 2.2 \\
\hline Seldom true of me & 5 & 11.1 \\
\hline Sometimes true of me & 17 & 37.8 \\
\hline Often true of me & 7 & 15.6 \\
\hline Definitely true of me & 15 & 33.3 \\
\hline
\end{tabular}

Item No. 18: My teacher's neatness \& attractiveness helps me to groom my personality.

\begin{tabular}{|l|l|l|}
\hline Responses & Frequency & Percentage \\
\hline Definitely not true of me & 4 & 8.9 \\
\hline Seldom true of me & 5 & 11.1 \\
\hline Sometimes true of me & 11 & 24.4 \\
\hline Often true of me & 5 & 11.1 \\
\hline Definitely true of me & 20 & 44.4 \\
\hline
\end{tabular}

Item No. 19: My teacher's habit of solving the problems motivates me to solve the problems of others.

\begin{tabular}{|l|l|l|}
\hline Responses & Frequency & Percentage \\
\hline Definitely not true of me & 4 & 8.9 \\
\hline Seldom true of me & 3 & 6.7 \\
\hline Sometimes true of me & 10 & 22.2 \\
\hline Often true of me & 7 & 15.6 \\
\hline Definitely true of me & 21 & 46.7 \\
\hline
\end{tabular}

Item No. 20: My teacher's good manner motivates me to behave well with others.

\begin{tabular}{|l|l|l|}
\hline Responses & Frequency & Percentage \\
\hline Definitely not true of me & 2 & 4.4 \\
\hline Seldom true of me & 7 & 15.6 \\
\hline Sometimes true of me & 4 & 8.9 \\
\hline Often true of me & 10 & 22.2 \\
\hline Definitely true of me & 22 & 48.9 \\
\hline
\end{tabular}

Item No.21: My teacher's punctuality makes me punctual too.

\begin{tabular}{|l|l|l|}
\hline Responses & Frequency & Percentage \\
\hline Definitely not true of me & 1 & 2.2 \\
\hline Seldom true of me & 5 & 11.1 \\
\hline Sometimes true of me & 9 & 20.0 \\
\hline Often true of me & 10 & 22.2 \\
\hline Definitely true of me & 20 & 44.4 \\
\hline
\end{tabular}


Item No. 22: My teacher's well maintained personality helps me to manage my self.

\begin{tabular}{|l|l|l|}
\hline Responses & Frequency & Percentage \\
\hline Definitely not true of me & 5 & 11.1 \\
\hline Seldom true of me & 7 & 15.6 \\
\hline Sometimes true of me & 8 & 17.8 \\
\hline Often true of me & 9 & 20.0 \\
\hline Definitely true of me & 16 & 35.6 \\
\hline
\end{tabular}

Item No. 23: My teacher's contemplation of social traditions \& moral values also helps me to keep these values.

\begin{tabular}{|l|l|l|}
\hline Responses & Frequency & Percentage \\
\hline Definitely not true of me & 4 & 8.9 \\
\hline Seldom true of me & 8 & 17.8 \\
\hline Sometimes true of me & 17 & 37.8 \\
\hline Often true of me & 13 & 28.9 \\
\hline Definitely true of me & 4 & 8.9 \\
\hline
\end{tabular}

Table No.24 The CHI- SQUARE was run to see the association between the preferences of male and female students

\section{Chi-Square Tests}

\begin{tabular}{|l|l|l|l|}
\hline & Value & df & Asymp. Sig. (2-sided) \\
\hline Pearson Chi-Square & $28.125(\mathrm{a})$ & 29 & .511 \\
\hline Likelihood Ratio & 38.599 & 29 & .110 \\
\hline Linear-by-Linear Association & .091 & 1 & .763 \\
\hline N of Valid Cases & 45 & & \\
& & & \\
\hline
\end{tabular}

The above table shows that there is no difference between the preferences of male and female students regarding the characteristics and traits of the teachers ( chi- square value=28.15, sig $=.51$ ).

\section{Conclusion}

An overall view that can be extracted from this research is that teachers' characteristics and traits influence students' behavior and personality. It also reveals that students prefer a teacher who has positive traits and characteristics including excited behavior, punctuality, emotional stability, trust worthiness, positive attitude towards students, sincerity with job, polite and loving behavior, good out look, giving importance to students' problems, and overall observation of moral values. All most all students believe that teachers' both positive and negative characteristics affect students' character their personality.

\section{Recommendations}

Following recommendations are made on the basis of findings and conclusion:

1. The teacher should respect the student's diversity and give love and caring attitudes toward students with special needs, because his caring attitudes could have a long positive or negative influence on students. Student's self-esteem could be lift up because it could create ambitions in their minds for future success.

2. The teacher should manage the social problems of the students with special needs.

3. The teacher should guide the students about their personality grooming as a role model.

4. Teacher should model good conduct to develop positive characteristics in their students. 


\section{References}

Ahsin, M \& Ahmed, H. A. (2007). A study of teacher student relationship in the schools of children with hearing impairment .Un published Masters Thesis, Department of Special Education, University of the Punjab, Lahore.

Amanat, S \& Shahbaz, N (2008). The impact of teachers' personality on the character building of children with hearing impairment. Un published Masters Thesis, Department of Special Education, University of the Punjab, Lahore.

Berliner, D.C. (1986). In pursuit of the expert pedagogue. Educational Researcher, 15, 5-13.

Brophy, J. (1986). Teacher influences on student achievement. American Psychologist, 41(10), 1069-1077.

Brophy, J., \& Good, T. (1986). Teacher behavior and student achievement. In M. Broudy, H.S., Ennis, R.H.,\& Krimerman, L.I. (1973). Philosophy of Educational Research. New York: John Wiley and Sons, Inc.

Characteristics of effective special education teacher retrieved on October, 8, 2012 from www.alleducationschools.com leducation.../special-education/teaching.

Characteristics of human beings retrieved on October, 10, 2012 retrieved fromwww.gurusoftware.com/GuruNet/Personal/Factors.htm

Clark, C.M. (1993). The good teacher. English Teachers' Journal: Israel, 46, $29-34$.

Dalton, S. S. (2007). Five standards of effective teaching: How to succeed with all learners, grades k-8. Jhon Wiley \& Sons, Inc.

Feist, J. \& Fiest, G.J. (2006) Theories of personality.(6th Ed.). (America): McGraw hill Companies, Inc.

foundation for accountability through excellence. ERIC Document Reproduction Service No. ED 358061.

Giladi, M. and Ben-Peretz, M. (1981). Student-teacher's views of teachers. Studies in Education, 30:5-14.

Hall, C. S. \& Lindzey, G. (1957). Theories of personality. New York, NY: John Wiley \& Sons

Leaman, L. (2008). The perfect teacher: How to make the very best of your teaching skills. Continuum International Publishing Group.

Moore, A. (2004) The good teacher: Dominant discourses in teaching education. (London and New York): Routledge Falmer

Morrison, G. S. (1997). Teaching in America. Boston: Allyn and Bacon.

Personality traits of human beings retrieved on October, 12, 2012 from en.wikipedia.org/wiki/Big_Five_personality_traits

Scheopner, A. J. (2005). Building Character in Schools: Resource Guide: A book review. Teaching exceptional children plus, 2(1)

Shanoski, L.A. \& Hranitz, J.R. (1992). Learning from America's best teachers: Building 